\author{
${ }^{1}$ Т. Глущенко, ${ }^{2}$ Т. Бедыч*, ${ }^{1}$ Б.Сакенов, ${ }^{1}$ Г.Хабдуллина \\ ${ }^{1}$ А.Байтурсынов атындағы Қостанай мемлекеттік университеті, Қостанай, Қазақстан \\ ${ }^{2}$ М. Дулатов атындағы Қостанай инженерлік-экономикалық университеті, Қостанай, Қазақстан \\ *e-mail: tatyana194@inbox.ru
}

\title{
БИОЭТАНОЛДЫ АЛУҒА АРНАЛҒАН БИОМАССА РЕСУРСТАРЫ
}

\begin{abstract}
Аңдатпа. Мақалада биоэтанол өндіру үшін жаңартылатын энергияны пайдалану мәселелері қарастырылған. Қостанай облысы дамыған ауыл шаруашылығы саласы болып табылады. Жердің көп бөлігі дәнді дақылдар мен жүгерінің, майлы дақылдар мен көкөністердің егіс алқаптарына бөлінген. Аграрлық дақылдарды өндіру, тасымалдау, сақтау және өңдеу процесінде өсірілген дақылдардың едәуір бөлігі жарамсыз болып қалады. Оларды кейіннен негізгі мақсаты бойынша пайдалану мүмкін емес. Көбінесе қорланбаған өрістерде шіріп кетеді немесе лақтырылады. Мақалада қарастырылған материал ауылшаруашылық қалдықтарын салыстырмалы түрде арзан биоэтанолды өндіру үшін пайдалануға болатындығын көрсетеді. Өңірде халықтың басым бөлігі ауыл тұрғындары. Елді мекендер бір-бірінен алыс қашықтықта орналасқан. Ауыл тұрғындарының қажеттіліктерін, ауылдық инфрақұрылымдарды қамтамасыз ету үшін биоэтанолды электр және жылу энергиясының көзі ретінде пайдалану ұтымды болар еді. Биоэтанол өндірісінің қалдықтары мал азығына жарамды, бұл ауылдық жерлер үшін және қоршаған ортаға экологиялық жүктемені азайту үшін де маңызды.Адамның өмір сүру процесінде биоэтанол алуға, содан кейін жылу және электр энергиясын алуға жарамды қатты тұрмыстық қалдықтар жасалады. Келтірілген есептеулер қатты тұрмыстық қалдықтарды биоэтанолға өңдеудің орындылығын көрсетеді. Еуроодақ елдері өз ғалымдарының зерттеулерін пайдалана отырып, биоэтанол мен синтетикалық отын түрлерін өндіру жөніндегі технологияларды табысты дамытуда. Қазақстан майлы дақылдарды өңдеу тәжірибесі мен қажетті егіс алқаптарына ие бола отырып, биоэтанол өндіру саласын табысты дамыта алады. Осы бағытта Қазақстанда осы уақытқа дейін зерттеулер жүргізілген жоқ. Биоэтанолды қолдану тұтынушыларды сапа стандарттарына сәйкес келетін өзіндік энергия көздерімен қамтамасыз етуге мүмкіндік береді. Осылайша, өңірдің энергетикалық қауіпсіздігін арттыру, атмосфераға зиянды шығарындылар санын азайту, ауыл тұрғындары еңбек ете алатын шағын энергетика кәсіпорындарын құру.
\end{abstract}

Негізгі сөздер: биомасса, биоэтанол, қатты тұрмыстық қалдықтар, ағынды сулардың тұнбасы, жаңартылатын энергия көздері.

Кіріспе. Жаңартылатын энергияның ең әмбебап көзі-биомасса. Фотосинтез нәтижесінде өсімдіктер энергия жинай алады және әртүрлі мақсаттарда икемді түрде қолдана алады. Әдетте қатты биомасса, биомассадан алынған газ және ішкі жану қозғалтқыштары мен пештерде жану үшін жарамды сұйық жанғыш заттар қолданылады. Биомассаны пайдалану тұрмыстық қалдықтар мен ауылшаруашылық қалдықтарын өңдеумен байланысты проблемаларды азайтуға мүмкіндік береді. Сонымен қатар, ауылшаруашылық аймақтар екі есе пайда көреді: олар ауыл шаруашылығында да, орман шаруашылығында да, биоэнергияны түрлендіру процесінде де қосымша жұмыс орындарын ашады [1]. Биоэнергетика үшін дақылдарды өсіру фермерлерге жаңа қызмет саласын ұсынады.

Биоэнергетика энергия өндірісін орталықсыздандыруға және материалдар мен энергияның жабық циклын құруға мүмкіндік береді. Биомасса өсімдіктердің өсу процесінде сіңірілген көмірқышқыл газының мөлшерін ғана шығарады. $\mathrm{CO}_{2}$ балансы тұрғысынан биоотын бейтарап.

Биоэнергияның көздері әртүрлі болуы мүмкін. Олар алу әдісімен, жану кезінде көрінетін қасиеттерімен және пайдалану мүмкіндіктерімен ерекшеленеді. Биоэнергияны қатты, сұйық және газ тәрізді отынды өндіру үшін қолдануға болады [2].

Қатты биомасса, ең көп таралған жаңартылатын энергия көзі бола отырып, бүкіл әлемде энергияны өндіру үшін бұрыннан бері қолданылып келеді $[3,4]$. Қатты биомассаға құрғақ немесе кептірілген өсімдіктердің немесе олардың бөліктерінің барлық түрлері, соның ішінде ағаш, ағаш түйіршіктері (түйіршіктер) және брикеттер, ағаш жоңқалары, бағаналы масса, күріш қауызы және т.б. жатады [5]. Қазіргі заманғы жылумен жабдықтау жүйелерінде қатты биомассаны жағу 
нәтижесінде өндірілетін энергия тиімділігі жоғары. Ағаш энергияның бастапқы көзі болып табылады, әсіресе бөренелер, үгінділер және түйіршіктер түрінде [6,7].

Биогаз негізінен блоктық жылу электр станцияларында қолданылады, бірақ сонымен бірге табиғи газбен жабдықтау жүйелеріне тікелей жеткізу үшін де қолданылады. Сонымен қатар, оны көлік құралдарына отын ретінде пайдалануға болады.

Қазіргі уақытта биоотынның негізгі түрлері-биодизель және биоэтанол. Биодизель отынын өндіру үшін рапс, күнбағыс тұқымы, соя, жаңғақтар және пальма сүйектері сияқты майлардың көп мөлшері бар өсімдіктер қолданылады [8]. Биоэтанол қант пен крахмал бар биомассадан алынады. Биоэтанол негізінен көлік құралдары үшін қолданылады.

Биоотынды пайдалану адамдар мен қоршаған орта үшін аз қауіпті. Жану кезіндегі биоотын $\mathrm{CO}_{2}$ балансы тұрғысынан бейтарап.

Кәдімгі спирт сияқты, биоэтанол ашытқымен қантты ашыту арқылы алынады, содан кейін тазартылады. Егер дәнді дақылдар қолданылса, алдымен крахмал ферментативті реакция нәтижесінде бөлініп, қантқа айналады. Бұл құрғақ барда түрінде жанама өнімнің пайда болуына әкеледі, оның құрамында шамамен 30\% ақуыз бар, сондықтан жануарлардың құнды тамағы болып табылады [9]. Қант қызылшасынан биоэтанол өндіруде қалдықтар-бұл мал азығы немесе тыңайтқыш ретінде пайдаланылатын қант қызылшасының бардасы мен целлюлозасы [2]. Спирттен кейінгі бардтың бір килограмына биоэтанолдың бір литрін өндіреді. Осылайша, қант қызылшасының бір гектарынан отынның мөлшері алынады, ол 80000 км асады, ал алынған жем бір сиырға шаққанда 9 айға жетеді.

Әдістері. Солтүстік Қазақстан елеулі аумақтарға бөлінген және электр, сондай-ақ жылу энергиясының энергетикалық ресурстарын тұтынушылар болып табылатын дамыған ауыл шаруашылығымен сипатталады. Осыған байланысты елді мекендер мен шаруашылықтарды өз энергия көздерімен қамтамасыз ету қажеттілігі туындайды. Биоэнергияның көзі дәнді және майлы дақылдардың қалдықтары, қарбыз, қатты тұрмыстық қалдықтар болуы мүмкін.

Тек Қостанай облысында жыл сайын дәнді және майлы дақылдар өсіріледі (1-кесте), олардың қалдықтары елеулі және оларды биоэтанал алу үшін пайдалануға болады.

Қазақстанның аграрлық секторы дәстүрлі түрде халықтың тұтынуы үшін қарбыз өсірумен айналысады. Соңғы жылдары бақша дақылдары үшін егіс алқаптарының шамамен 40\% өсуі байқалады. Қазақстанда бақша дақылдарын өндіру халықтың қажеттілігін толық қамтамасыз етеді.

1-кесте. Ауыл шаруашылығы дақылдарынан биоэтанол өндіру әлеуеті

\begin{tabular}{|c|c|c|c|c|c|c|}
\hline $\begin{array}{c}\text { Биомасса } \\
\text { түрі }\end{array}$ & $\begin{array}{c}\text { Жалпы } \\
\text { жиын, } \\
\text { мың т. }\end{array}$ & $\begin{array}{c}\text { Қалдықт } \\
\text { ар саны, } \\
\text { мың т. }\end{array}$ & $\begin{array}{c}\text { Этанолдың } \\
\text { шикізат } \\
\text { тоннасына } \\
\text { шығуы }\end{array}$ & $\begin{array}{c}\text { Барлық } \\
\text { этанолдың } \\
\text { шығуы, т }\end{array}$ & $\begin{array}{c}\text { Тоннаның } \\
\text { бағасы, } \\
\text { теңге }\end{array}$ & $\begin{array}{c}\text { Жиыны, } \\
\text { мың теңге }\end{array}$ \\
\hline $\begin{array}{c}\text { Астық } \\
\text { тұқымдас } \\
\text { мәдениет }\end{array}$ & 4454,56 & 668,184 & 455 & 304023,7 & 52780 & $\begin{array}{c}16046 \\
371,9\end{array}$ \\
\hline $\begin{array}{c}\text { Дәндік } \\
\text { жүгері }\end{array}$ & 125,06 & 18,759 & 412 & 7728,708 & 49010 & 378783,9 \\
\hline Қарбыз & 205,83 & 41,166 & 21 & 864,486 & 36569 & 31613,4 \\
\hline Картоп & 373,31 & 37,331 & 94 & 3509,114 & 60320 & 211669,8 \\
\hline Жиыны & & & & & & 16636 \\
825,6 \\
\hline
\end{tabular}

Егер біз қарбыз туралы айтатын болсақ, онда өсіп келе жатқан жемістер мен зақымдалған қарбыздар егістіктерде жиналмайды. Қарбыздарды құстар зақымдайды, сондықтан олар толық жетілуге жете алмайды, тауарлық түрін жоғалтады және өрістерде қурап қалады. Тасымалдау кезінде жидектің бір бөлігі зақымдалып, жарамсыз болып қалады [10]. 
Қарбыздың 20\% астамы «тауарлық» көріністің болмауына байланысты сөрелерге түспейді: олар бүлінген немесе дұрыс емес пішінді. Мұндай жидектерді биоэтанолды өндіру үшін пайдалануға болады.

Этанол алу үшін биомассаның осы көздерінен басқа, шөп, сабан және мәдени өсімдіктердің жемістерін пайдалана аласыз: алма, шие, алмұрт. Солтүстік Қазақстан аймағында күрт континенталды климатқа қарамастан, қалдықтар мен сапасыз жемістерді этанол өндіру үшін пайдалануға болатын жеміс өсіріледі $[11,12]$.

Жүргізілген зерттеу ауыл шаруашылығы өндірісінің қалдықтарын биоэтанолға өңдеудің орындылығын көрсетеді.

Этанол алу үшін жоғарыда аталған көздерден басқа, қалалық коммуналдық тазарту қондырғыларын, кейбір өнеркәсіптік салалардың органикалық қалдықтарын, қалалардың қатты тұрмыстық қалдықтар полигондарын (полигондар) пайдалануға болады.

Қатты тұрмыстық қалдықтардың пайда болу нормалары қабылданады (ҚТҚ)[13]:

- қала тұрғындары үшін-1,2 кг/адам·тәулігіне 50\% ылғал кезінде;

- ауыл тұрғындары үшін- 0,52 кг/адам·тәулігіне (ауылдық жерлерде тамақ қалдықтары үй жануарлары мен құстардың жемі үшін пайдаланылады және қалдықтардың құрамына кірмейді деп болжанады).

Жылу шығару қабілеті (ҚТҚ) құрғақ заттың (ҚТҚ) бір тоннасына 0,2 ш.о.т. (мұнай баламасына) тең деп қабылданады. Ылғалдылығы 50\% болатын тұрмыстық қалдықтар құрғақ деп саналады [14].

Өңірде бір жыл ішінде құрылатын ҚТҚ экономикалық әлеуеті 2-кестеде келтірілген.

«Атамекен» ұлттық кәсіпкерлер палатасының деректері бойынша 2018 жылға қарай Қазақстанда 43 млрд тоннадан астам өндіріс және тұтыну қалдықтары жинақталған, олардың тек 9\% ғана қайта өңделеді. Көбінесе біздің елде олар қағазға, шиналарға және пластиктің кейбір түрлеріне жаңа өмір береді. Ірі қалаларда қоқысты бөлек жинау науқаны басталды, жаңа өңдеу зауыттары іске қосылды. Мұндағы басты шикізат-қайта өңделген макулатура.

Қағаз-қаптама қоқысы бүкіл Қазақстан бойынша жиналады: әңгіме тек 14 облыс орталығы мен республикалық маңызы бар 3 қала туралы ғана емес. Ресейдің кейбір шекаралас аймақтарында серіктестер де бар.

\section{2-кесте. ҚТҚ-ның экономикалық әлеуеті}

\begin{tabular}{|c|c|c|c|c|c|}
\hline $\begin{array}{c}\text { Ауданның, елді } \\
\text { мекеннің атауы }\end{array}$ & $\begin{array}{c}\text { Халық } \\
\text { саны }\end{array}$ & $\begin{array}{c}\text { Энергияның } \\
\text { жалпы } \\
\text { потенциалы } \\
\text { (ҚТҚ) }\end{array}$ & $\begin{array}{c}\text { Ауданның, елді } \\
\text { мекеннің атауы }\end{array}$ & $\begin{array}{c}\text { Халық саны } \\
\text { Энергияның } \\
\text { потенциалы } \\
\text { (ҚТК) }\end{array}$ \\
\hline чел & т.у.т. & & чел & т.у. \\
\hline Алтынсарин & 14114 & 535,77 & Мендіқара & 27841 & 1056,84 \\
\hline Амангелді & 16673 & 632,91 & Наурызым & 11080 & 420,60 \\
\hline Әулиекөл & 42991 & 1631,94 & Сарыкөл & 20976 & 796,25 \\
\hline Денисов & 18824 & 714,56 & Таран & 25432 & 965,40 \\
\hline Жангелді & 12550 & 476,40 & Ұзынкөл & 21479 & 815,34 \\
\hline Жетіқара & 48755 & 1850,74 & Федоров & 25953 & 985,18 \\
\hline Қамысты & 12764 & 484,52 & Арқалық & 41354 & 3622,61 \\
\hline Қарабалық & 27966 & 1061,59 & Костанай & 239652 & 20993,52 \\
\hline Қарасу & 25834 & 980,66 & Лисаков & 40842 & 3577,76 \\
\hline Қостанай & 70468 & 2674,97 & Рудный & 130068 & 11393,96 \\
\hline жиыны & & & & & $\mathbf{5 5 6 7 1 , 5 2}$ \\
\hline
\end{tabular}


Қатты тұрмыстық қалдықтарды қайта өңдеу нәтижесінде миллион тоннаға жуық этанол алуға болады (3-кесте).

Егер әрбір үшінші тұрғын жылына екі килограмм газет пен журнал тұтынады деп болжасақ, онда қосымша алты жүз тоннадан астам этанол алуға болады [15].

\section{3-кесте. ҚТҚ - дан биоэтанол өндіру әлеуеті}

\begin{tabular}{|c|c|c|c|c|c|}
\hline $\begin{array}{c}\text { Биомасса } \\
\text { түрі }\end{array}$ & $\begin{array}{c}\text { Жалпы жиын, } \\
\text { мың т. }\end{array}$ & $\begin{array}{c}\text { Этанолдың } \\
\text { шикізат } \\
\text { тоннасына } \\
\text { шығуы }\end{array}$ & $\begin{array}{c}\text { Этанолдың } \\
\text { шығуы, т }\end{array}$ & $\begin{array}{c}\text { Тоннаның } \\
\text { бағасы, } \\
\text { теңге }\end{array}$ & $\begin{array}{c}\text { Жиыны, мың } \\
\text { теңге }\end{array}$ \\
\hline ҚТҚ & 55671,52 & 17 & 946415,8 & 9425 & 8919969292 \\
\hline $\begin{array}{c}\text { Газеттер мен } \\
\text { журналдар }\end{array}$ & 22,182 & 29 & 643,278 & 5655 & 3637737 \\
\hline
\end{tabular}

Нәтижелері. Жоғарыда келтірілген есептеулер көрсеткендей, аймақтың елді мекендері аймақтың энергия көздеріне қажеттілігін толық немесе ішінара қамтамасыз ете алады. Егер Қостанай қаласының полигондарына жыл ішінде миллион тоннаға жуық тұрмыстық қатты қалдықтар жағылатынын ескеретін болсақ, онда қалдықтарды пайдалану қаланы толығымен отынмен қамтамасыз етуге мүмкіндік береді.

Зерттеу нәтижесінде қорытынды жасауға болады:

- ауыл шаруашылығы өндірісінің қалдықтарын биоэтанолға қайта өңдеу шаруа қожалықтарына жаңартылатын энергияның қосымша көзін алуға мүмкіндік береді;

- алынған, экологиялық таза отын тұтынушылардың орталық газбен жабдықтаудан қашықтығы жағдайында жылу және электр энергиясын өндіру үшін пайдаланылуы мүмкін; мүмкін.

- құрғақ барда, дақылдардың қалдықтарын өңдеу нәтижесі, мал азығына пайдаланылуы

Талқылау. Энергия ресурстарын үнемдеуден басқа, мұндай көз қалдықтарды өңдеу мәдениетін және табиғатқа барынша ұқыпты қарауды қалыптастырады, электр энергиясы мен жылуды орталықтандырылған жеткізушілерден энергетикалық тәуелсіздік үшін жағдай жасайды.

\section{REFERENCES}

[1] Rocha-Meneses, L., Raud, M., Orupxld, K. \& Kikas, T. 2017. Second-generation bioethanol production: A review of strategies for waste valorization. Agronomy Research 15(3), 830-847.

[2] Kundas, S.P., Pozniak, S.S. \& Shenets, L.V. 2009. Renewable energy sources, Minsk, Belarus, $315 \mathrm{pp}$.

[3] Sibikin, Yu,D. \& Sibikin, M.Yu. 2009. Unconventional renewable energy sources. Moscow, Russia, 232 pp.

[4] Chetoshnikova, L.M. 2010. Unconventional Renewable Energy Sources. Study Guide, Chelyabinsk, Russia, 69 pp.

[5] Yang, Ziqi, Wu, Yuanqing, Zhang, Zisheng. 2019. Recent advances in co-thermochemical conversions of biomass with fossil fuels focusing on the synergistic effects. Renewable \& sustainable energy reviews Book 103, Published: APR, pp 384-398.

[6] Girones, V.C. \& Peduzzi, E.F., 2018. On the Assessment of the CO2 Mitigation Potential of Woody Biomass. Frontiers in Energy Research: Book 5, Article No.: UNSP 37 Published: JAN 24.

[7] McKendry, P. 2002. Energy production from biomass (part 2): conversion technologies Bioresource Technology 83, pp 47-54.

[8] Ismuratov, S.B., Bedych, T.V., Glushchenko, T.I., Ismuratov, D.S. \& Kukhar, V.S. 2019. Forecasting model for capacity of autonomous power station. International Journal of Mechanical Engineering and Technology (IJMET), Volume 10, Issue 02, 0976-6340 and ISSN Online: 0976-6359

[9] Glushchenko, T., Bedych, T., Podvalnyy, V. \& Cherkasov, Y. 2019. The structure of closed energy cycle with self-regenerating soil fertility. Atlantis press Advances in Intelligent Systems Research, 
volume 167 International Scientific and Practical Conference Digitization of Agriculture - Development Strategy, (ISPC 2019), pp. 306-309.

[10] Chandra, R., Takeuchi, H. \& Hasegawa, T. 2012. Methane production from lignocellulosic agricultural crop wastes: A review in context to second generation of biofuel production. Renewable and Sustainable Energy Reviews 16(3), 1462-1476.

[11] Bauer, A., Busch, P., Friedl, A. \& Amon, T. 2009. Analysis of methane potentials of steamexploded wheat straw and estimation of energy yields of combined ethanol and methane production. Journal of Biotechnology 142(1), 50-55.

[12] Vissarionov, V.I. 2009. Methods for calculating renewable energy resources. Study Guide. Moscow, Russia, 144 pp.

[13] Raud, M., Kesperi, R., Oja, T., Olt, J. \& Kikas, T. 2014. Utilization of urban waste in bioethanol production: Potential and technical solutions. Agronomy Research 12, 397-406.

[14] Vitkovskaya, S.E. 2012. Solid domestic waste is an anthropogenic link in biological cycle. St. Petersburg, Russia, 132 pp.

[15] Grinin, A.S. 2002. Industrial and household waste. Storage, untilization, recycling. Moscow, Russia, Grand FAIR-PRESS, pp. 330-334.

\section{${ }^{1}$ Т. Глущенко, ${ }^{2}$ Т. Бедыч*, ${ }^{1}$ Б.Сакенов, ${ }^{1}$ Г.Хабдуллина}

${ }^{1}$ Костанайский государственный университет им. А.Байтурсынова, Костанай, Казахстан

${ }^{2}$ Костанайский инженерно-экономический университет им. М. Дулатова, Костанай, Казахстан

*e-mail: tatyana194@inbox.ru

\section{РЕСУРСЫ БИОМАССЫ ДЛЯ ПОЛУЧЕНИЯ БИОЭТАНОЛА}

Аннотация. В статье рассмотрены вопросы использования возобновляемой энергии для производства биоэтанола. Определены ресурсы биомассы для получения биоэтанола. Приведена биоэнергетическая оценка сельскохозяйственных отходов для переработки в биоэтанол. Рассмотрена возможность использования твердых бытовых отходов в качестве сырья для получения биоэтанола.

Ключевые слова: биомасса, биоэтанол, твердые бытовые отходы, осадки сточных вод, возобновляемые источники энергии.

${ }^{1}$ T. Glushchenko, ${ }^{2}$ T. Bedych*, ${ }^{1}$ B. Sakenov, ${ }^{1}$ G.Khabdullina

${ }^{1}$ Kostanay State University named after A. Baitursynov, Kostanay, Kazakhstan

${ }^{2}$ Kostanay Engineering and Economic University named after M. Dulatova, Kostanay, Kazakhstan

*e-mail: tatyana194@inbox.ru

\section{BIOMASS RESOURCES FOR PRODUCTION OF BIOETHANOL}

Abstract. The article deals with the use of renewable energy for the production of bioethanol. The resources of biomass for the production of bioethanol have been determined. The bioenergy assessment of agricultural waste for processing into bioethanol is presented. The possibility of using solid household waste as a raw material for producing bioethanol is considered.

Key words: biomass, bioethanol, municipal solid waste, sewage sludge, renewable energy sources. 